\title{
STRATEGI ADAPTASI PEMASARAN KERAJINAN TENUN ULOS PADA PASAR TRADISIONAL, MODERN DAN ON LINE DI TAPANULI UTARA (Studi di Kota Tarutung)
}

\author{
Harisan Boni Firmando \\ IAKN Tarutung \\ boni.harisan@iakntarutung.ac.id
}

\begin{abstract}
The writing of journal entitled "Strategy of Marketing Adaptation for Ulos (woven cloth) at Tradisional, Modern and On Line Market in North Tapanuli (Study in Tarutung City)" was begin on the increasing of the number of Ulos merchant at traditional, modern and on line market in North Tapanuli. Merchant the advanced age had change the competition map by build a new marketing strategy. By the entering of the new competitors in the business encourage the entrepreneurs or merchant to have optimal thinking to achieve goal namely to seek and maintain the existence of the customer who has an important rule in the survive of market circulation. The approach method applied in this research is descriptive method by qualitative approach. The data was collected by observation and interview. The analysis unit and information in this research is the merchant and customer of ulos at Tarutung City. The data is interpreted by using the field record. The results of research indicates that the higher of market competition in the area, either in Tarutung or out of Tarutung encourage the merchant of ulos assure the customer through creativity or product innovation.
\end{abstract}

Keywords: Strategy Marketing, Adaptation, Social association, Social network.

\begin{abstract}
Abstrak
Penulisan jurnal yang berjudul "Strategi Adaptasi Pemasaran Kerajinan Tenun Ulos di Pasar Tradisional, Modern dan Online di Tapanuli Utara (Studi di Kota Tarutung)" dimulai dengan peningkatan jumlah pedagang Ulos di pasar tradisional, modern dan on line di Tapanuli Utara. Pedagang usia lanjut telah mengubah peta persaingan dengan mengembangkan strategi pemasaran baru. Dengan masuknya pesaing baru dalam bisnis, mendorong pengusaha atau pedagang untuk memiliki pola pikir yang optimal untuk mencapai tujuan menemukan dan mempertahankan keberadaan pelanggan yang memiliki aturan penting dalam kelanjutan sirkulasi pasar. Metode yang digunakan dalam penelitian ini adalah metode deskriptif dengan pendekatan kualitatif. Data dikumpulkan dengan observasi dan wawancara. Unit analisis dan informasi dalam penelitian ini adalah pedagang dan pelanggan Ulos di Kota Tarutung. Data ditafsirkan menggunakan catatan lapangan. Hasil penelitian menunjukkan bahwa semakin tinggi persaingan pasar di daerah, baik di Tarutung atau di luar Tarutung mendorong pedagang ulos untuk meyakinkan pelanggan melalui kreativitas atau inovasi produk.
\end{abstract}

Kata kunci: Strategi Pemasaran, Adaptasi, Perkumpulan sosial, Jejaring sosial.

\section{Pendahuluan}

Pasar adalah tempat terjadinya interaksi antara penjual dan pembeli. Pasar merupakan pusat dan ciri pokok dari jalinan tukar-menukar yang menyatukan 
seluruh kehidupan ekonomi. Di dalam pasar terdapat tiga unsur, yaitu: penjual, pembeli dan barang atau jasa yang keberadaannya tidak dapat dipisahkan. Pertemuan antara penjual dan pembeli menimbulkan transaksi jual-beli, akan tetapi bukan berarti bahwa setiap orang yang masuk ke pasar akan membeli barang, ada yang datang ke pasar hanya sekedar main saja atau ingin berjumpa dengan seseorang guna mendapatkan informasi tentang sesuatu.

Pada pasar dijual kerajinan tenun tradisional suatu daerah, misalnya di pasar Tarutung dan pusat perbelanjaan modern di Sumatera Utara terdapat tenun ulos dan songket yang diperjual belikan. Dahulu ulos adalah sesuatu yang sakral dan sangat tinggi nilainya dalam adat Batak. Ulos dirajini sepenuhnya dari benang yang diciptakan dari tumbuh-tumbuhan dan pewarna alami. Penenunannya pun dilakukan dengan tangan sehingga memakan waktu yang sangat lama untuk menyelesaikan satu lembar. Secara tradisional, ruang tenun terletak di kolong rumah-panggung, penenun ulos secara tradisional adalah perempuan.

Ulos dikenal sebagai ekspresi kasih-sayang, maka dikenal ungkapan mangulosi. Dalam adat Batak, mangulosi (memberikan ulos) melambangkan pemberian kehangatan dan kasih sayang kepada penerima ulos. Dalam hal mangulosi, ada aturan umum yang harus dipatuhi, yaitu mangulosi hanya boleh dilakukan kepada orang yang mempunyai status kekerabatan atau sosial lebih rendah, misalnya orang tua boleh mangulosi anaknya, tetapi sang anak tidak boleh mangulosi orang tuanya. Demikian juga dengan ulos yang hendak digunakan untuk mangulosi harus mempertimbangkan tujuan dari pemberian ulos tersebut.

Melihat begitu pentingnya fungsi ulos dalam masyarakat Batak, maka upaya pelestariannya harus segera dilakukan. Pelestarian tentunya tidak hanya dimaksudkan agar keberadaan ulos tersebut tidak punah, tetapi juga merevitalisasinya sehingga memberikan manfaat bagi orang-orang Batak yang melestarikannya. Revitalisasi harus dilakukan secara hati-hati sehingga tidak melunturkan nilai-nilai yang dikandung oleh kain ulos. Pelestarian dan revitalisasi tidak boleh hanya berorientasi pada nilai ekonomi saja, tetapi juga nilai-nilai yang terkandung di dalamnya, sehingga masyarakat Batak tidak mengalami alienasi dan tercerabut dari akar lokalitasnya.

Dengan lahirnya mesin tenun, harga 'ulos mesin' menjadi lumrah dan murah. Begitu apik tenunan mesin itu sehingga 'ulos halus' bukan lagi sesuatu 
yang harus dibeli mahal. Inilah awal pudarnya kejayaan ulos asli hasil tenunan tangan para pengrajin tradisional. Dengan menurunnya minat akan ulos asli, menurun pula minat warga untuk menjadi penenun ulos tradisional. Para penenun ulung yang wafat terpaksa membawa pergi pula kearifannya karena langkanya ahli waris penerus. Dari masa ke masa, kearifan tenun asli Batak kian punah, beberapa jenis tenunan adat pun punah untuk selamanya. Menenun ulos bukan lagi suatu ketrampilan melainkan sudah kearifan karena melembagakan pengetahuan yang terdapat dari budaya tenun yang telah hidup ratusan tahun di dalam masyarakat setempat. Masyarakat Batak saat ini semakin sedikit yang memiliki keterampilan dalam menenun ulos, namun disisi lain ulos tetap dibutuhkan dalam berbagai acara, keadaan inilah yang membuat masyarakat batak harus membeli ulos yang sudah ditenun atau diproduksi mesin.

Para penenun dan pedagang tenun ulos kini terbilang cukup ramai yang menggeluti bisnis ulos. Ada penjual biasa yang terdapat di pasar tradisional dan ada penjual kelas atas yang ada di butik seperti yang terdapat di mal dan ada pula penjualan langsung secara on line. Tenunan ulos yang akan dijual selama ini didapatkan dari daerah-daerah Sub-sub Etnis Suku Batak seperti di Kabupaten Simalungun, Karo, Toba Samosir, Samosir, Tapanuli Utara, Tapanuli Selatan. Terkadang mereka juga mendapat ulos yang bukan dari tenunan orang tetapi dari pabrikan besar yang memproduksi jenis ulos secara besar-besaran.

Dilihat dari segi sosiologis berjalannya proses pemasaran para pedagang kerajinan ulos di pasar tradisional, modern dan on line ditunjang oleh biaya sosial yang terlihat dari berjalannnya peranan modal sosial. Hal itu ditandai dengan bertambahnya jumlah pedagang dari tahun ke tahun sejak tahun 1980an hingga saat ini. Para pedagang umumnya merupakan penduduk daerah Tapanuli bahagian utara, dimana mereka telah menggeluti usaha ulos, baik sebagai penenun maupun pedagang ulos di kampung halaman masing-masing. Antara penenun dan pedagang satu sama lain umumnya memiliki hubungan kekerabatan. Ada pula pedagang yang melanjutkan usaha orang tuanya berdagang ulos. Fokus penelitian disini adalah Strategi Adaptasi Pemasaran pengrajin kerajinan tenun ulos pada pasar tradisional dan modern studi strategi penenun dan pedagang dari Tapanuli Utara. 


\section{Kajian Teori}

\section{Teori Struktural Fungsional}

Suatu fungsi adalah kumpulan kegiatan yang ditujukan ke arah pemenuhan kebutuhan tertentu atau kebutuhan sistem. Dengan menggunakan defenisi ini, Parsons yakin bahwa ada empat fungsi penting diperlukan semua sistem yaitu adaptation (A), goal attainment (G), integration (I), dan latensi (L) atau pemeliharaan pola. Secara bersama-sama, keempat imperatif fungsional ini dikenal sebagai skema AGIL.

Parsons mendesain skema AGIL untuk digunakan di semua tingkatan dalam sistem teoritisnya. Dalam bahasan tentang empat sistem tindakan, akan dicontohkan bagaimana cara Parsons menggunakan skema AGIL. Organisme Perilaku adalah sistem tindakan yang melaksanakan fungsi adaptasi dengan menyesuaikam diri dengan dan mengubah lingkungan eksternal. Sistem kepribadian melaksanakan fungsi pencapaian tujuan dengan menetapkan tujuan sistem dan memobilisasi sumber daya yang ada untuk mencapainya. Sistem sosial menanggulangi fungsi integrasi dengan mengendalikan bagian-bagian yang menjadi komponennya. Terakhir, sistem kultural melaksanakan fungsi pemeliharaan pola dengan menyediakan aktor seperangkat norma dan nilai yang memotivasi mereka untuk bertindak ${ }^{1}$.

\section{Teori Modal Sosial}

Modal sosial dapat didiskusikan dalam konteks komunitas yang kuat (strong community), masyarakat sipil yang kokoh, maupun identitas negarabangsa (nation-state identity). Modal sosial, termasuk elemen-elemennya seperti kepercayaan, kohesivitas, altruisme, gotong-royong, jaringan, dan kolaborasi sosial memiliki pengaruh yang besar terhadap pertumbuhan ekonomi melalui beragam mekanisme, seperti meningkatnya rasa tanggungjawab terhadap kepentingan publik, meluasnya partisipasi dalam proses demokrasi, menguatnya keserasian masyarakat dan menurunnya tingkat kekerasan dan kejahatan.

Modal sosial mirip bentuk-bentuk modal lainnya, dalam arti ia juga bersifat produktif. Modal sosial dapat dijelaskan sebagai produk relasi manusia satu sama lain, khususnya relasi yang intim dan konsisten. Modal sosial menunjuk pada jaringan, norma dan kepercayaan yang berpotensi pada produktivitas 
masyarakat. Namun demikian, modal sosial berbeda dengan modal finansial, karena modal sosial bersifat kumulatif dan bertambah dengan sendirinya. Karenanya, modal sosial tidak akan habis jika dipergunakan, melainkan semakin meningkat. Rusaknya modal sosial lebih sering disebabkan bukan karena dipakai, melainkan karena ia tidak dipergunakan. Berbeda dengan modal manusia, modal sosial juga menunjuk pada kemampuan orang untuk berasosiasi dengan orang lain. Bersandar pada norma-norma dan nilai-nilai bersama, asosiasi antar manusia tersebut menghasilkan kepercayaan yang pada gilirannya memiliki nilai ekonomi yang besar dan terukur ${ }^{2}$.

\section{Metode Penelitian}

Metode yang digunakan dalam penelitian ini adalah metode penelitian deskriptif dengan menggunakan pendekatan kualitatif. Sebagaimana yang dikemukakan oleh Taylor dan Bogman dalam Bagong Suyanto dan Sutinah ${ }^{3}$ bahwa penelitian kualitatif dapat diartikan sebagai penelitian yang menghasilkan data deskriptif mengenai kata-kata lisan maupun tertulis, dan tingkah laku yang dapat diamati dari orang-orang yang diteliti. Penelitian kualitatif juga dapat diartikan sebagai pendekatan yang menghasilkan data, tulisan, dan tingkah laku yang di dapat dari apa yang diamati ${ }^{4}$. Metode penelitian deskriptif merupakan jenis penelitian yang bertujuan untuk memberikan gambaran mengenai sesuatu masalah $^{5}$. Dengan demikian penelitian ini menggambarkan fakta-fakta tentang bagaimana strategi adaptasi yang dilakukan oleh para penenun dan pedagang kerajinan tenun ulos dari Tapanuli Utara di pasar tradisional dan modern agar dapat memperluas pemasaran.

\section{Hasil dan Pembahasan}

\section{Strategi Pemasaran Pengrajin Kerajinan Tenun Ulos}

Pasar adalah suatu tempat atau proses interaksi antara permintaan (pembeli) dan penawaran (penjual) dari suatu barang/jasa tertentu, sehingga akhirnya dapat menetapkan harga keseimbangan (harga pasar) dan jumlah yang diperdagangkan. Yang menjadi topik dalam penelitian ini adalah bagaimana strategi pemasaran yang dilakukan untuk menarik minat pembeli, sebagai faktor berjalannya pemasaran kerajinan ulos yang akan dijual. Ulos adalah pakaian tradisional yang menjadi kebutuhan primer bagi suku Batak, dikarenakan ulos 
digunakan pada setiap kegiatan adat baik sukacita maupun dukacita. Ulos juga dihubungkan dengan identitas atau posisi seseorang dalam suatu acara, kelas seseorang bahkan kini sampai kepada tren ataupun gaya hidup seseorang. Dengan semakin berkembangnya zaman, ulos kini dilirik sebagai usaha yang memiliki prospek ke depan. Hal itu dilakukan dengan mengubah penampilan ulos hingga semenarik mungkin dengan model yang beraneka ragam.

Secara sosiologis latar belakang penenun dan pedagang ulos adalah suku Batak, dari segi kekuatan (strength) dan kesempatan (opportunity) hal ini menjadi peluang besar untuk berjalannya proses pemasaran antara penjual dan pembeli. Mata rantai strategi adaptasi pemasaran kerajinan ulos oleh penenun dan pedagang dari Tapanuli Utara dapat menjadi salah satu faktor pendorong peningkatan mutu produksi melalui indikator strategi pemasaran, yaitu: Jaringan Sosial, Hubungan (Relationship), Pelabelan, dan Sosialisasi Produk.

\section{Jaringan Sosial}

Strategi pemasaran bergantung pada peningkatan produktivitas penjualan dan pembelian dari konsumen pembeli ulos, serta perlu pula adanya penekanan beban biaya yang dikeluarkan. Kerajinan tenun ulos yang diproduksi secara tradisional dari daerah Lumbanjulu, Porsea, Laguboti, Balige, Tarutung, Sipirok, maupun yang menggunakan mesin dari daerah Siantar, Sidikalang di kumpulkan oleh pengumpul, kemudian dipasok ke pasar tradisional, modern dan on line untuk di pasarkan ke berbagai daerah. Proses produktivitas dari penenun hingga pendistribusian kerajinan tenun ulos tersebut ke pembeli/pelanggan di bantu oleh adanya peranan jaringan sosial.

Peranan jaringan sosial dapat dilihat melalui perkumpulan sosial yang telah menjadi mitra kerja pengrajin kerajinan ulos dalam membantu pedagang memasok dan memasarkan produk ulos. Peranan perkumpulan sosial seperti perkumpulan keagamaan, marga, arisan, serikat tolong menolong, asal daerah, secara langsung merupakan media promosi untuk menarik minat pembeli sehingga menjadi pendorong kegiatan pemasaran ulos. Ulos yang digunakan dalam berbagai kegiatan yang berhubungan dengan acara adat tidak terlepas dari hubungan dengan perkumpulan sosial, dimana anggota dalam perkumpulan sosial membutuhkan ulos dalam berbagai acara adat. Mereka kemudian saling berkomunikasi dan bertukar informasi dimana membeli dan dijual ulos yang baik 
dengan pelayanan yang ramah dan harga yang murah, kemudian mengarahkan temannya untuk membeli di salah pedagang, dengan demikian proses pendistribusian ulos dapat sampai ke pembeli/pelanggan. Jaringan sosial dan strategi pemasaran terfluktiatif dalam aspek urgensi sebagai berikut:

Bussiness Summary $\rightarrow$ Company History $\rightarrow$ Industry Predible $\rightarrow$ Manufacturing Plan $\rightarrow$ Products $\rightarrow R \& D \rightarrow$ Consumerism $\rightarrow$ Producing $\rightarrow$ Financial Pro forma $\rightarrow$ Advantage $\rightarrow$ Appendice $\rightarrow$ Local Economic $\rightarrow$ Distribution.

\section{Hubungan (Relationship)}

Hubungan dipengaruhi karena adanya faktor sedarah, kedaerahan, dan kenalan. Hubungan antara penenun, pengumpul, pemasok, pedagang dan pembeli/pelanggan dapat dilihat dari sistem pendistribusian ulos. Ulos yang telah ditenun secara tradisional maupun yang telah dicetak dengan mesin dikumpulkan oleh pengumpul/penggelas. Setelah dikumpulkan penggelas, ulos kemudian diberikan kepada pemasok yang kemudian pemasok mendistribusikan ulos-ulos tersebut ke pasar trasisional dan modern. Adapula penggelas yang juga bekerja sebagai pemasok. Setelah berada di pasar para pedagang, pemasok, dan pelanggan sama-sama melakukan kegiatan pemasaran kerajinan tenun ulos ke berbagai daerah yang membutuhkan ulos.

Hubungan yang terjalin di antara penenun, pengumpul/penggelas, pemasok dan pedagang ulos dari Tapanuli Utara memiliki hubungan kekerabatan satu sama lain yang didasari oleh hubungan marga atau asal daerah. Hubungan kekerabatan secara langsung membantu kegiatan pemasaran ulos, apabila pedagang belum mampu membayar ulos yang dipesan dengan uang tunai dari penenun atau pemasok, pedagang dapat meminta kelonggaran waktu pembayaran, setelah ulos tersebut laku dijual baru dibayar. Demikian pula pedagang akan mendapatkan potongan harga jika ada membeli dalam ukuran yang banyak, seperti satu kodi dari penenun atau pemasok. Adanya hubungan darah telah membantu pedagang kerajinan ulos dari Tapanuli Utara bertahan dalam kegiatan pemasaran. Ditemui banyak pengrajin kerajinan ulos dari Tapanuli Utara yang melanjutkan usaha dari orang tuanya. Salah satu alasan mereka tetap menggeluti usaha ini karena telah menguasai sistem pemasarannya dan usaha ini memiliki untung yang besar dengan tingkat kesulitannya yang kecil. 
Diantara sesama pedagang kerajinan ulos dari Tapanuli Utara dapat terlihat adanya hubungan yang kuat satu sama lain, yang didasari oleh adanya rasa percaya. Rasa percaya tersebut membantu para pedagang dalam memasarkan produk kerajinan ulos. Apabila pedagang yang tidak mempunyai salah satu barang ulos dia tidak sungkan-sungkan untuk mengambil atau meminjam barang tetangga atau temannya, pedagang sering pula merujuk pembeli ke pedagang temannya yang lain. Begitu pula dalam hal permodalan, para penenun dan pendagang yang kurang memiliki modal akan meminjam modal berupa uang ataupun barang dari pedagang besar daripada meminjam dari bank. Pedagang memilih meminjam dari pedagang besar karena pinjaman dari bank memiliki bunga pinjaman yang nantinya dapat menjadi penghalang pada proses perkembangan usaha.

\section{Diversivikasi Produk}

Diversifikasi atau penganekaragaman produk dilakukan penenun ulos di Tapanuli Utara dengan melakukan variasi produk. Varisasi produk dilakukan agar produk ulos tersebut dapat bersaing dalam menarik pelanggan serta adanya permintaan dari pelanggan. Variasi ulos dilakukan berdasarkan berapa lama ulos tersebut tahan digunakan, model, keperluan, modifikasi dan proses penenunan ulos secara tenun tradisional maupun mesin modern. Agar penjualan ulos dapat bersaing dengan pedagang ulos yang ada, para penenun berinovasi meningkatkan kualitas ulos. Peningkatan kualitas ulos tersebut terlihat dari desain dan fitur/corak ulos yang diminati oleh pelanggan. Penenun sering berkomunikasi dengan pelanggan tentang corak/model apa yang diminati pelanggan atau yang sedang naik daun saat ini. Setelah mengetahui permintaan pelanggan penenun kemudian menenun motif tersebut. Dalam diversifikasi produk ulos, para pedagang ulos juga membuat kemasan pembungkus ulos yang menarik seperti ukuran, bentuk, warna yang menarik serta tampilan gambar desain/corak ulos di plastik kemasan, yang memberikan manfaat optimal melindungi produk sehingga praktis dan aman bagi pembeli untuk membawa kemasan pembungkus tersebut dan menyimpannya.

Para pedagang melakukan strategi diferensiasi (perbedaan) untuk menarik pelanggan datang membeli, kerajinan ulos yang ada pada mereka berbeda dengan yang ada di kios atau pedagang yang lain. Diferensiasi produk pemasaran dapat dilihat berdasarkan bentuk ulos tersebut dimana ulos tersebut memiliki keistimewaan (features) dibandingkan ulos yang lain, keistimewaan itu terlihat 
dari kualitas kinerja (performance quality) pengerjaan ulos tersebut seperti hasil tenunan yang halus serta berapa lama daya tahan (durability) ulos tersebut dapat dipakai. Diferensiasi produk ulos juga dilakukan pula dengan memodifikasi ulos dengan kualitas kesesuaian (conformance quality) perkembangan gaya (style) yang ada saat ini. Modifikasi ulos dilakukan dengan memproduksi ulos dengan cara tradisional dan merancangnya dengan perkembangan model tanpa meninggalkan nilai-nilai yang terkandung dalam ulos tersebut (heritage) dengan demikian ulos tersebut lebih handal dibanding ulos lainnya.

Permintaan ulos tenun tangan lebih banyak diminati oleh pelanggan dari pada ulos mesin cetak, walaupun harga jualnya lebih tinggi berkisar Rp. 1.500.000 - Rp. 3.500.000. Permintaan itu dikarenakan ulos tenun tangan bentuknya lebih bagus dan nilainya lebih tinggi, dapat dilihat dari bentuk ulos yang lebih lebar dan lebih panjang, ketebalan ulos, daya tahan pemakaian ulos, kenyamanan dalam pemakaian. Selain itu ulos tenun memiliki keindahan corak yang beraneka ragam dan corak/motif tersebut tampak jelas dilihat dari dekat maupun dari jauh.

\section{Sosialisasi Produk}

Salah satu cara sosialisai produk yang dilakukan adalah pemberian label sebagai bentuk sosialisasi produk. Dengan mencantumkan label, maka label dapat berfungsi sebagai tanda pengenal terhadap produk yang dijual atau dipasarkan. Label memberikan kemudahan kepada pelanggan untuk mengidentifikasi produk atau merek, label juga dapat menggambarkan dan menjelaskan beberapa hal mengenai pembuat kerajinan ulos tersebut, dimana ulos tersebut dibuat, bagaimana cara ulos tersebut dibuat melalui tenun tradisional atau mesin cetak (mesa), bagaimana bentuk ulos tersebut, bagaimana penggunaannya dan bisa mempromosikan produk lewat aneka gambar yang menarik.

Sosialisasi produk juga dilakukan melalui pembuatan merek seperti pemberian nama, tanda, simbol yang membedakan produk ulos yang dipasarkan terhadap pesaing. Para pedagang ulos di pasar tradisional dan modern menggunakan esensialitas merek dengan indikator nilai dari suatu merek. Pemberian nama merupakan strategi yang ampuh untuk menarik pelanggan yang berasal dari mayoritas suku yang sama yaitu suku Batak. Untuk memberikan daya tarik kepada pelanggan para pedagang membuat marga mereka menjadi nama 
toko agar para pelanggan tertarik datang ke kios mereka. Misalnya dengan mencantumkan nama Toko Ulos "UD Nainggolan", maka merek tersebut mempunyai loyalitas merek yang mencirikan hubungan saluran (ascribed status) berdasarkan marga (dalam kajian sosiologis ekonomis tercakup dalam Managing Order Licency) merupakan sebuah daya tarik dalam Sosialisasi Produk. Pelanggan yang memiliki marga atau memiliki hubungan dengan marga Nainggolan akan datang ke kios/toko ulos tersebut dan membeli ulos dari kios tersebut.

Sosialisasi merupakan proses akhir dari pemasaran. Produk yang akan dijual mempunyai determinasi nilai dalam memberi peluang berjalannya proses pemasaran. Hal ini dapat terlihat dari skema pendekatan sosiologis strategi adaptasi pemasaran melalui transaksi jual beli dibawah ini.

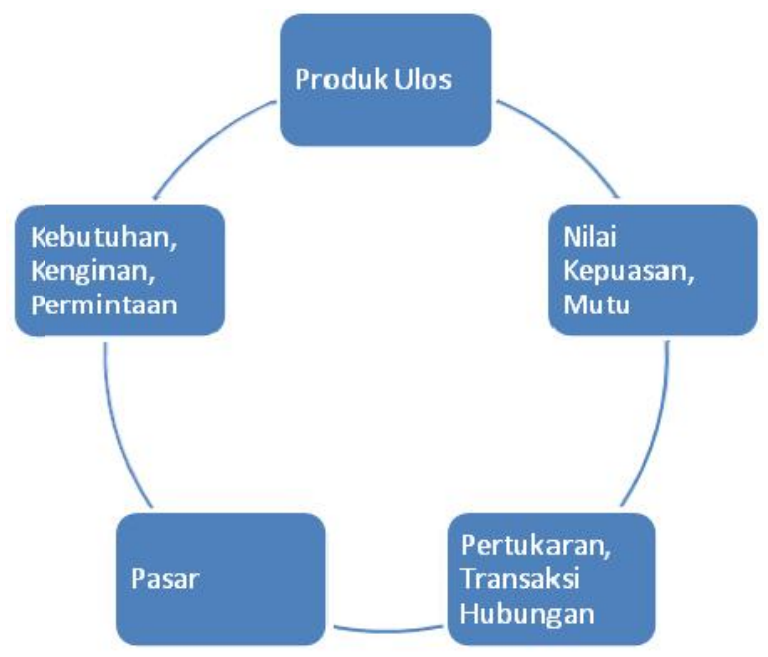

Gambar 1 Skema Transaksi Jual Beli Ulos

Ada beberapa hal yang secara kajian sosiologi sebagai indikator pemasaran, melihat dari fungsionalisme pasar sebagai penjual dan pembeli. Penjual mempunyai cara tersendiri agar menarik pembeli untuk tetap membeli ulos. Kondisi pasar mempunyai nilai yang dapat dimanfaatkan pedagang dengan tujuan agar proses pendistribusian barang berjalan dengan baik, pedagang menggunakan cara untuk berjalannya indikator strategi pemasaran yang ada yaitu dengan : adaptasi, pencapaian tujuan, integrasi dan latensi/ pemeliharaan pola.

\section{a. Adaptasi}

Sistem sosial berawal dari hubungan dua pihak atau lebih, dimana pihak tersebut harus mampu menyesuaikan diri dengan lingkungan yang dihadapinya baik berupa lingkungan fisik maupun sosial. Untuk dapat beradaptasi dengan baik diperlukan adanya Hubungan yang baik (Relationship) antara pedagang dengan 
pelanggan. Hubungan yang baik itu dilakukan pedagang kerajinan tenun ulos di Pasar tradisional dan modern melalui pelayanan yang baik terhadap pembeli.

Pelayanan yang baik dari pedagang seperti tegoran dan rayuan kepada calon pembeli akan membuat calon pembeli datang ke kios pedagang untuk membeli dan akan kembali lagi membeli pada waktu yang akan datang. Inilah cara yang dilakukan oleh pedagang kerajinan tenun ulos di Pasar untuk memberi kesan pertama yang baik kepada calon pelanggan, dimana kesan pertama yang baik merupakan penarik bagi pelanggan untuk datang kembali di kemudian hari. Tindakan pedagang menyangkut prilaku pedagang yang merupakan cara (usage) dalam memberikan pelayanan kepada konsumen yaitu berupa tegoran dan rayuan.

Strategi yang dilakukan pedagang untuk dapat beradaptasi dengan situasi lingkungan yang berkembang saat ini adalah dengan membuat kemasan pembungkus ulos yang rapi, yang membuat penampilannnya tidak kalah dengan hasil kerajinan ulos yang ditawarkan di pasar modern seperti butik di mal. Kemasan pembungkus itu berupa plastik putih transparan yang di dalamnnya dimasukkan ulos sehingga bisa disimpan di rumah dan dibawa ke luar kota. Pedagang juga membuat kartu nama yang memuat berbagai informasi seperti nama pedagang, aneka kerajinan yang dijual, alamat dan nomor kontak serta media sosial pedagang, kartu nama tersebut diberikan kepada orang yang meminta atau orang yang sudah selesai berbelanja. Disamping itu ada pula kantongan plastik dengan aneka warna, yang berfungsi sebagai kemasan pembungkus dan sumber informasi, dimana di luar kantongan plastik tersebut terdapat tulisan yang berisikan aneka jenis ulos yang diperjual belikan dan beragam informasi dari pedagang. Perkembangan teknologi juga dimanfaatkan penenun dan pedagang dengan menggunakan kekuatan media sosial. Hasil tenunan dipromosikan melalui youtube, facebook, instagram, twitter dan WA serta aplikasi belanja on line seperti tokopedia, bukalapak, shope, blibli, lazada.

\section{b. Pencapaian Tujuan}

Dalam pencapaian tujuan tindakan sebuah sistem harus mencapai tujuan utamanya. Tujuan pedagang kerajinan tenun ulos adalah agar barang dagangannya cepat laku. Agar barang dagangan cepat laku, sering kali para pedagang memberikan harga yang murah kepada pelanggan yang dijadikan tata kelakuan (folkways). Dengan demikian pelanggan akan tertarik sebab aneka ulos dengan 
beragam model diperjual belikan dengan harga yang terjangkau. Rata-rata ulos tersebut di jual dengan harga Rp. 50.000 - Rp. 3.500.000,-.

Para pedagang ulos biasanya memberikan harga yang miring kepada para pelanggan yang baru pertama kali membeli ulos. Hal ini dilakukan supaya nantinya pelanggan tersebut datang kembali ke kios itu untuk membeli ulos dan menunjukkan kios penjual ulos tersebut kepada rekan-rekannnya agar membeli ulos dari tempat itu saja.

Harga murah yang diberikan pedagang kepada pelanggan memberi kepuasan tersendiri kepada pelanggan. Pelanggan tidak perlu lagi mengeluarkan banyak biaya untuk membeli ulos yang cantik, hanya dengan harga yang sudah diberikan pedagang dan sedikit menawar maka pelanggan akan mendapatkan harga yang miring. Di sisi lain, pelanggan tidak perlu repot lagi untuk berkeliling di pasar, tapi pelanggan sudah langsung tahu ke kios atau pedagang mana akan pergi membeli jenis ulos yang dicari.

Berjualan di lokasi yang strategis menjadi strategi pedagang kerajinan tenun ulos di pasar untuk mencapai tujuan. Kios yang strategis yaitu kios yang dekat dengan pintu utama atau pintu masuk lainnya. Lokasi kios yang strategis membawa kondisi yang menguntungkan kepada pedagang. Oleh karena itu para pedagang berlomba-lomba membeli ataupun menyewa lokasi yang strategis di pasar. Pedagang yang bermodal pas-pasan tidak mampu membeli atau menyewa kios di lokasi strategis sehingga berjualan di lokasi yang kurang strategis.

Agar pemasaran dapat berjalan dengan lancar para pedagang juga melakukan strategi membuka kios setiap hari. Dengan membuka kios setiap hari maka proses pemasaran dapat terus berlangsung tanpa adanya hambatan, seperti hari libur umum. Strategi ini masih dilakukan oleh beberapa kios, dikarenakan sebagian besar pedagang ulos beragama Kristiani, maka sebagian besar pedagang tutup pada hari minggu. Dalam situasi pedagang yang tutup pada hari minggu maka proses pemasaran ulos di salah satu kios akan terhambat. Salah satu pedagang mengungkapkan strategi mereka membuka kios setiap hari.

Pedagang yang setiap hari membuka kios di pasar Tarutung akan memiliki omset yang lebih tinggi bila dibandingkan oleh pedagang yang tidak membuka kios setiap hari. Hal ini dikarenakan persaingan usaha dalam merekrut pelanggan di hari libur umum sangat kecil tidak seperti hari biasa. Misalnya Pedagang yang 
membuka kios pada hari minggu akan mendapat keuntungan karena kios-kios yang lain tidak terbuka sehingga pelanggan akan membeli ke tempat mereka.

Seiring dengan perkembangan zaman yang membutuhkan efisensi dan efektivitas, kini proses jual beli kerajinan tenun ulos tidak hanya dilakukan di pasar. Saat ini transaksi jual beli sudah langsung dari penenun kepada pembeli, tidak lagi dari penenun, pengumpul, pemasok, pedagang dan pembeli. Penenun dapat langsung berhubungan dengan pelanggan dengan media komunikasi ataupun melalui media sosial. Penggunaan kekuatan media komunikasi dan media sosial saat ini dirasakan sangat efektif oleh para penenun dan pedagang. Kehadiran media komunikasi modern bagi para penenun sangat membantu proses kerajinan tenun ulos mulai dari proses pembuatan sampai proses jual beli, sehingga dua tujuan penenun dan pedagang dapat tercapai. Tujuan pertama penenun adalah agar ulos dapat selesai dengan kualitas baik dan sesuai dengan keinginan pembeli, hal ini dapat dicapai dengan diikutinya mode terkini oleh penenun dari media modern seperti youtube atau media sosial dan komunikasi dengan pelanggan melalui WA. Setelah tujuan pertama tercapai, kehadiran media modern juga menghantarkan tercapainya tujuan kedua, yaitu tercapainya proses jual beli. Transaksi jual beli dapat tercapai dengan kekuatan media sosial ataupun aplikasi jual beli online.

\section{c. Integrasi}

Agar suatu sistem sosial dapat berfungsi secara efektif maka diperlukan adanya tindakan solidaritas di antara individu-individu terlibat. Integrasi merujuk pada kebutuhan untuk menjamin ikatan emosional yang mampu menghasilkan solidaritas dan kerelaan untuk bekerja sama dapat dikembangkan dan dipertahankan. Pasar menjadi sebuah tempat yang menghasilkan rasa solidaritas dan kerelaan untuk bekerjasama dan di tempat ini pula terjadi proses jual beli.

Bermula dari pasar para pedagang, pengumpul, pemasok, dan pelanggan bersama-sama melakukan kegiatan pemasaran kerajinan tenun ulos ke berbagai daerah yang membutuhkan ulos. Kerajinan tenun ulos yang berasal dari Siantar, Porsea, Laguboti, Balige, Tarutung, Sipirok, dan Sidikalang, dikirim ke Pasar, dimana Pasar berfungsi sebagai tempat dikumpulkannya berbagai kerajinan tenun ulos tersebut. Ulos yang sudah terkumpul pada pedagang kemudian disebarkan 
dan dipasarkan ke daerah-daerah di dalam dan luar Sumatera Utara seperti Pekan Baru, Jakarta, Surabaya, hingga Papua.

Pedagang kerajinan tenun ulos sudah sejak tahun 1980 an atau sekitar empat puluh tahun berdagang ulos di pasar tradisional. Dari tahun ke tahun pertumbuhan pedagang ulos di pasar tradisional semakin bertambah. Pertambahan pedagang itu dikarenakan pasar tradisional sebagai sentral pemasaran kerajinan tenun ulos ke berbagai daerah. Selain itu usaha penjualan kerajinan tenun ulos merupakan usaha yang menjanjikan omset yang tinggi bagi pedagang ulos.

Setelah ulos tersebut dipasarkan ke berbagai daerah maka terjadilah proses jual beli yang akan berlangsung secara berulang-ulang dalam waktu yang tidak ditentukan. Pedagang dapat sewaktu-waktu datang ke tempat pemasok untuk membeli tenunan atau menghubungi penenun/pemasok untuk mengirimkan tenunan ulos ke Pasar. Hal yang sama juga dapat dilakukan pelanggan, dimana pelanggan dapat sewaktu-waktu datang ke Pasar membeli ulos sesuai kebutuhannya atau menelepon pelanggan untuk mengirimkan ulos pesanannya.

\section{d. Latensi / Pemeliharaan Pola}

Suatu sistem sosial diharapkan mampu mengatasi kemungkinan bahwa suatu saat para anggotanya akan merasa letih dan jenuh sehingga mengarah pada berhentinya interaksi. Oleh karena itu sebuah sistem harus memperlengkapi, memelihara, dan memperbaiki, baik motivasi individual maupun pola-pola kultural yang menciptakan dan menopang motivasi ${ }^{6}$. Agar komitmen terhadap kelompok tetap utuh sehingga interaksi sistem dapat dilanjutkan, maka strategi yang dilakukan pedagang adalah dengan membuat tampilan kios menarik dengan menjual beraneka ragam barang-barang kerajinan untuk keperluan adat Batak.

Aneka barang kerajinan untuk keperluan adat Batak yang dipamerkan untuk di jual pada kios pedagang pasar berupa ulos dan pakaian adat lengkap dari beragam daerah seperti Toba, Mandailing, Angkola, Karo, Simalungun, Pak-Pak, begitu pula dengan songket, songket Tarutung, Palembang, Thailand. Pedagang juga menjual kebaya, asesoris, souvenir khas Batak, hingga tandok (sumpit untuk menyimpan beras). Adanya aneka barang kerajinan tersebut di sebuah kios, membuat pelanggan tidak perlu lagi pergi ke kios lain untuk membeli barang lain karena lengkap sudah terdapat di pedagang tersebut. 
Strategi lain yang dilakukan pedagang dalam pemeliharaan pola adalah membuat tampilan modern dengan cara tradisional tanpa meninggalkan nilai-nilai budaya (heritage) dalam proses produksi ulos. Melihat situasi dan kondisi masyarakat saat ini yang membutuhkan selera atau model baru maka penenun dan pedagang mulai memodifikasi ulos-ulos yang diperjual belikan dengan tampilan yang baru. Tampilan baru tersebut dapat dilihat dari corak, penambahan bordir, air mas, manik-manik dan rumbe-rumbe pada kerajinan tenun ulos.

Pedagang kerajinan tenun ulos sering bertanya bertanya kepada pelanggan, motif ulos apa yang sedang naik daun saat ini. Demikian juga pelanggan sering kali menunjukkan motif ulos yang sedang naik daun saat ini melalui handphone milik pelanggan. Setelah melihat motif ulos yang dipesan pelanggan, pedagang memesan kepada penenun, apabila motif tersebut tidak ada, pedagang meminta penenun untuk menempahkannya. Bila pedagang sudah memiliki ulos dengan tampilan baru, maka kios pedagang itu akan ramai dikunjungi pelanggan.

Veblen memandang selera sebagai senjata dalam kompetisi ${ }^{7}$. Kreativitas selera disalurkan melalui model yang akhirnya diwakili oleh simbol-simbol dari kemodrenan. Cara inilah yang dipakai oleh pedagang kerajinan tenun ulos sebagai salah satu strategi. Pemeliharaan pola yang merupakan salah satu persyaratan fungsional terlihat dari model melalui pengkombinasian bahan baru dengan ulos tradisional yang menghasilkan ulos modern. Para pembeli ulos pada umumnya akan melirik ulos model baru tapi tetap menggunakan mesin tenun tradisional bukan dengan mesin cetak (meca/mesa), hal ini dikarenakan ulos yang menggunakan tenun tradisional lebih nyaman dipakai. Mengkombinasikan ulos tenun dengan bahan-bahan modern adalah langkah awal yang dilakukan pedagang untuk menarik perhatian calon konsumen yang lewat didepan kios pedagang ulos, sehingga calon konsumen bereaksi menghampiri kios tersebut.

\section{Implementasi Modal Sosial Dalam Proses Pemasaran}

Hubungan antara pedagang, pamasok dan pelanggan terjadi dalam proses pemasaran yang dilakukan secara berulang-ulang. Relasi yang dibangun membutuhkan proses dan waktu yang cukup lama. Interaksi sosial yang tinggi berguna untuk membangun hubungan di antara pedagang, pemasok dan pelanggan. Hubungan yang baik ini berpengaruh kepada keputusan penetapan harga. Keputusan penetapan harga tersebut dipengaruhi oleh rasa percaya, 
jaringan sosial dan norma. Berjalannya peranan modal sosial ini sangat membantu semua pihak, sehingga semua pihak sama-sama mendapat keuntungan.

\section{Rasa Percaya Dalam Proses Pemasaran Di Antara Pedagang, Pemasok, Dan Pelanggan}

Adanya rasa percaya (trust) merupakan hal yang terpenting dalam hubungan perdagangan di Pasar. Rasa percaya yang ada diantara pedagang menghasilkan ikatan sosial yang erat antara pedagang, pemasok dan pelanggan. Adanya rasa percaya berdampak positif terhadap keberlangsungan usaha pedagang. Bila dilihat dari latar belakang sukunya, mayoritas para pedagang kerajinan ulos di pasar berasal dari suku yang sama yaitu suku Batak, oleh karena itu rasa percaya yang ada bersifat familiar.

Adanya rasa percaya juga menghasilkan kewajiban sosial, dengan mempercayai seseorang akan menimbulkan kepercayaan kembali dari orang tersebut (resprositas) ${ }^{8}$. Dengan adanya hubungan reprositas yang terbina, maka proses jual beli akan tetap berjalan walaupun kios yang satu tidak memiliki ulos yang dipesan oleh pelanggan. Kondisi ini meminta pedagang memiliki kejujuran dalam mengambil barang dari kios lain dan menjualnnya kepada pelanggan. Hubungan kerja yang sudah ada dapat rusak jika pedagang mau untung sendiri. Dalam hal ini rasa kekeluargaan perlu semakin ditingkatkan agar antara pedagang yang satu dengan yang lain sama-sama mendapat untung.

Rasa percaya yang tumbuh dan terjalin tidak hanya terjadi di antara sesama pedagang di pasar. Rasa percaya juga terdapat pada pedagang pasar dengan pemasok yaitu penenun ulos yang berasal dari berbagai daerah. Rasa percaya membuat transaksi pembayaran dapat berjalan dengan lancar.

Pedagang pasar yang berhasil meningkatkan usahanya adalah pedagang yang mampu menjalin hubungan atas dasar rasa percaya. Hubungan yang dapat menggambarkan kebermanfaatan relasi yang didasari oleh trust adalah hubungan antara pedagang kerajinan ulos dengan pemasok pada sistem pembayaran dengan harga yang murah. Dimana pemasok akan memberikan harga yang murah kepada pedagang apabila pedagang banyak membeli kerajinan ulos dari pemasok atau penenun tersebut. Dengan demikian pedagang dapat menjual barang tersebut dengan murah kepada pelanggan dibandingkan pedagang ulos lainnya. 
Adanya rasa percaya antara pedagang dengan pengrajin ulos akan menghasilkan keuntungan di kedua belah pihak sehingga kedua belah pihak dapat meningkatkan usahanya. Hal itu dapat dilihat dari sistem pembayaran dimana beberapa pemasok ulos dari beragam daerah menggunakan sistem pembayaran yang berbeda, dimana pembayaran dapat dilakukan setelah aneka kerajinan ulos laku dijual oleh pedagang di pasar. Dengan cara ini banyak pedagang yang terbantu karena para pedagang ulos tidak perlu mengeluarkan modalnya untuk membeli ulos dari penenun, tapi justru sesudah ulos tersebut laku baru di bayar kepada penenun tersebut. Sistem pembayaran seperti ini dijumpai pada para pedagang yang memiliki hubungan keluarga dengan para pengrajin ulos.

Adapun faktor yang mendasari pedagang kerajinan ulos memberikan rasa percaya kepada pelanggan yaitu bertujuan untuk mencari banyak pelanggan sehingga mendapat keuntungan yang besar disamping itu dengan adanya rasa percaya antara pedagang dan pelanggan, maka diharapkan akan terciptanya jaringan dan semakin luasnya pemasaran. Menurut para pedagang, pelanggan yang telah lama bertahun-tahun menjadi langganan di kiosnya biasanya membeli barang dagangan dalam jumlah yang banyak untuk dipakai pada pesta atau untuk menjualnya kembali di kiosnya atau di rumahnya. Biasanya pelanggan yang membeli banyak tersebut dapat membayar sebagian dari uang ulos tersebut atau hingga ulos itu laku baru dibayar kepada pedagang pusat pasar. Ada pula pelanggan yang membayar ketika bulan muda, karena pembeli ulos yang dijual pelanggan membayar sesudah gajian. Hal ini dilakukan pedagang untuk membantu pelanggan sehingga ulos di kios pedagang cepat laku.

\section{Jaringan Sosial Dalam Cakupan Internal Proses Pemasaran}

Jaringan sosial ada dalam cakupan internal pada sistem pemasaran yang terdapat di pasar, diawali dari adanya rasa percaya dan sifat kekeluargaan antara pedagang, pemasok atau penenun, pegawai pasar, satuan pengamanan dan organisasi kepemudaan. Adanya komunikasi yang intens di antara pedagang, pemasok dan pelanggan dapat dilihat setiap hari di kios-kios penjual kerajinan ulos di Pasar merupakan gambaran kuatnya jaringan sosial. Demikian juga di kalangan pedagang pasar, mereka sangat akrab satu sama lain, terlihat pada waktu pedagang selesai merapikan kiosnya, pada jam makan siang atau ketika sepi pembeli. Keakraban itu terlihat ketika para pedagang berbicara dan bercanda 
gurau satu sama lain, bahkan bernyanyi bersama. Keakraban tersebut menghasilkan tingginya persatuan diantara pedagang ulos di pasar.

Persatuan yang dimiliki oleh penenun dan pedagang terlihat ketika salah seorang dari teman mereka mengalami sukacita atau dukacita. Dalam hal sukacita misalnya pesta kelahiran anak atau perkawinan, demikian juga dalam hal dukacita seperti kematian, para penenun dan pedagang datang mengunjungi keluarga yang bersukacita atau yang berdukacita. Dengan adanya hal seperti ini maka akan meningkatkan persatuan diantara sesama penenun dan pedagang. Terkhusus bagi para penenun dan pedagang kerajinan ulos yang mayoritas bersuku Batak, adanya sistem kearifan lokal seperti sistem kekerabatan Dalihan Na Tolu dalam suku Batak membuat rasa kekeluargaan di antara pedagang semakin kuat.

Di kalangan pedagang kerajinan ulos di pasar terdapat keunikan dimana pedagang membuat arisan. Adanya arisan ini sangat membantu para pedagang dalam hal permodalan. Bukti kuatnya jaringan sosial di antara pedagang ulos di pasar dalam memperluas pemasaran di tengah minimnya modal adalah dalam hal meminjam. Para pedagang yang mengalami kekurangan modal akan meminjam uang dari pedagang yang memiliki untung besar. Setelah waktu yang ditentukan misalnya dua minggu kemudian pedagang yang meminjam itu mengembalikan pinjamannya. Ada pula bentuk lain yaitu pedagang sering saling tukar-menukar barang dan mengambil kerajinan ulos dari kios tetanggannya apabila ulosnya habis, atau barang yang dipesan pelanggan tidak ada di kiosnya. Jaringan sosial antar pedagang yang kuat tampak pula ketika ada pedagang yang menghunjuk pelanggan untuk membeli ulos ke kios lain karena ulos tersebut tidak ada di kiosnya, nantinya hasil keuntungan penjualan dibagi rata.

Sikap tolong-menolong dalam hal pemasaran juga tampak dalam hubungan pedagang dengan pemasok atau penenun. Para pedagang biasanya tidak sungkan-sungkan meminta kepada pemasok agar ulos yang dikirim memiliki kualitas yang baik dengan harga yang murah agar pedagang ulos dapat bersaing dengan pedagang lainnnya dalam menarik pelanggan untuk menjadi pelanggan tetap. Pemasok sering menyetujui permintaan pedagang ini asalkan ulos yang dibeli oleh pedagang dalam jumlah yang banyak misalnya dalam jumlah satu kodi. Dengan demikian kedua belah pihak sama-sama diuntungkan pedagang akan tetap memasarkan ulos demikian juga pemasok akan tetap memproduksi ulos. 
Dalam hal pembayaran juga terjalin jaringan sosial yang baik antara pedagang dan pemasok. Para pedagang biasanya membayar ulos langsung melalui rekening pemasok atau supir angkutan yang membawa barang tersebut. Disisi lain sebagian dari para pedagang biasanya meminta kelonggaran waktu kepada pemasok atau penenun agar ulos yang dikirim ke tempat tujuan setelah laku dijual baru dibayar. Hal ini dikarenakan para pelanggan ulos yang berbelanja ke pasar tradisional banyak yang menjual ulos itu kembali.

Hal lain yang tampak kasat mata adalah adanya jaringan yang erat antara pedagang kerajinan ulos dengan pegawai pasar ditandai dengan adanya komunikasi yang amat baik diantara kedua belah pihak. Dimana bila kita berkunjung ke kantor pasar dapat dilihat ketika para pedagang ulos membayar pajak atau sewa kiosnya kepada pegawai pasar mereka berbincang-bincang tanpa ada rasa canggung satu sama lain. Demikian pula bila ada pegawai pasar yang membutuhkan ulos untuk keperluan adat pegawai Pasar sudah mengetahui pedagang ulos mana yang biasa menjadi langganannya. Pedagang ulos kemudian dengan cepat memberikan pesanan pegawai tersebut, dengan harga yang murah dengan kualitas yang baik.

Adanya hubungan yang baik diantara pedagang dengan satuan pengamanan dan organisasi kepemudaan adalah suatu bukti kekuatan jaringan sosial di pasar. Satuan pengamanan dan organisasi kepemudaan inilah yang selalu mengamankan kois-kios pedagang setiap saat sehingga bebas dari gangguan tindakan kriminalisme seperti pencurian. Dengan adanya peran satuan pengamanan dan organisasi pemuda yang ada di pasar maka terbantulah keberlangsungan proses pemasaran ulos di wilayah pasar.

Jaringan sosial dalam cakupan internal juga mencakup sebagian pelanggan. Pelanggan yang membeli ulos pada pasar tradisional di Tarutung sebagian besar adalah pedagang di daerahnya masing-masing. Para pelanggan tersebut ada yang berjualan di rumah mereka secara langsung maupun on line, di kios pasar tradisional, di wisma adat, di butik dan stand di mal. Interaksi antara pelanggan dan pedagang pasar juga ditandai dengan adanya komunikasi yang intens di kedua belah pihak, dimana pelanggan sering kali meminta pedagang untuk membuat corak model baru yang sedang musim saat ini. 
Untuk memperkuat jaringan sosial antara pedagang pasar dan pelanggan biasanya pedagang memberikan berbagai kemudahan kepada pelanggan agar mau mengambil ulos dari kiosnya. Para pedagang biasanya memberikan harga perkenalan bagi pembeli yang baru pertama kali membeli dan harga miring bila ada pelanggan yang membeli ulos dalam jumlah yang banyak misalnya hingga satu kodi. Pedagang pasar juga memberikan dispensasi waktu pembayaran kepada pelanggan yang menjual kembali tenunan ulos, karena pedagang tersebut juga menunggu pembayaran dari pembeli yang membeli ulos darinya.

\section{Jaringan Sosial Dalam Cakupan Eksternal Proses Pemasaran}

Rasa percaya telah menumbuhkan suatu hubungan yang kuat diantara pedagang dan pelanggan kerajinan ulos pada pasar. Hubungan yang kuat tersebut menghasilkan jaringan yang luas yang ditandai dengan terjadinya proses jual beli yang dilakukan secara berulang-ulang. Penenun dan pedagang kerajinan ulos yang memiliki banyak pelanggan menuturkan bahwa interaksi sosial yang bersifat kekeluargaan berperan penting dalam membantu berjalannya proses pemasaran.

Pada proses pemasaran di pasar ditemui beberapa hal yang mempengaruhi terbangunnya jaringan antara pedagang dengan pelanggan, yaitu adanya interaksi sosial yang akrab diantara pedagang dan pelanggan, adanya pemanfaatan hubungan antara pelanggan dengan pedagang misalnya karena adanya ikatan kekeluargaan, teman lama, kenalan, tetangga dan teman seperkumpulan sosial dan arisan yang membantu semakin luasnya pemasaran kerajinan ulos.

Terjalinnnya jalinan pertemanan yang sudah sejak lama juga membantu semakin luasnya hubungan pemasaran. Seorang pelanggan yang juga pedagang ulos di luar Tarutung menuturkan hubungan pertemanan yang sudah sejak lama membuat beliau selalu mengambil ulos dari salah satu kios di Pasar Tarutung untuk dijual ke salah satu pasar di daerah Tanjung Balai. Pelanggan menuturkan adanya rasa percaya dan keakraban dalam berkomunikasi membuat tidak berpindah membeli ke pedagang lain.

Hubungan perkenalan antara pedagang dengan pelanggan juga membantu proses pemasaran. Hal ini terjadi ketika pelanggan yang ingin membeli ulos dilayani dengan baik oleh pedagang dan akhinya membeli ulos di kios tersebut dan diberikan harga perkenalan. Kesan yang baik dari pedagang membuat pelanggan akan selalu membeli ulos di kios tersebut padahal sebelumnnya dia 
tidak pernah berbelanja di kios tersebut dan tidak pernah diberi petunjuk orang lain. Disamping itu hubungan perkenalan juga timbul karena pelanggan diberi petunjuk oleh seseorang untuk membeli ulos ke sebuah kios karena kios tersebut memiliki barang-barang yang berkualitas dari dulu.

Jaringan yang luas juga dipengaruhi oleh faktor bertetangga. Pedagang ulos pasar Tarutung biasanya memiliki ulos di rumah mereka, dimana sebahagian ulos tersebut akan dijual kepada tetangga yang ada jika mereka datang ke rumah untuk membeli ulos. Tetangga pedagang ulos sering merekomendasikan saudara atau temannnya untuk membeli ulos di kios milik tetangga mereka. Satu hal yang menarik adalah pedagang akan memberikan "uang teh" kepada tetangga, teman atau saudara mereka yang merekomendaskan kenalannnya untuk membeli ulos di kios pedagang ulos pasar Tarutung. Hal ini akan semakin memperkuat hubungan sosial yang berdampak pada perluasan pemasaran.

Dalam hal pemasaran ulos para pedagang juga sering membuat terobosanterobosan agar para kenalannnya datang membeli ulos kepada mereka. Para pedagang sering kali membuat motto "Dang Tumagon Tu Halak Adong Do Hita", atau "Adong Do Hita Di Son" yang artinya adalah "tidak baik membeli ke orang adanya kita" atau "adanya kita di sini". Dengan motto ini biasanya pihak keluarga akan selalu ingat dan disaat membutuhkan ulos, akan membeli ulos mereka.

Para pedagang pasar Tarutung yang mayoritas bersuku Batak Toba turut aktif dalam perkumpulan sosial. Perkumpulan-perkumpulan sosial tersebut dapat berupa perkumpulan marga, serikat tolong menolong, perkumpulan ibadah, asal daerah. Peranan perkumpulan sosial tersebut terhadap proses pemasaran sangat besar, hal ini dapat dilihat ketika ada salah seorang anggota perkumpulan yang akan mengawinkan anak, maka ia akan membeli ulos dari temannya sesama anggota perkumpulan dengan jumlah yang banyak. Demikian juga apabila ada anggota perkumpulan yang memiliki keluarga yang mengalami kemalangan maka mereka akan membeli ulos dengan jumlah yang banyak.

Peran perkumpulan sosial dalam memperluas jaringan pemasaran adalah sebagai alat untuk merekomendasikan pedagang ulos kepada kerabat atau kenalan mereka. Dengan demikian perkumpulan sosial secara langsung berperan sebagai media promosi dalam menarik minat pembeli. Biasanya para ibu-ibu sering bertanya satu-sama lain dimana mereka membeli ulos, maka ibu yang satu akan 
merekomendasikannya agar membeli ulos di salah satu pedagang. Ketika para ibu tersebut datang ke salah satu pedagang, mereka dilayani dengan lembut agar mereka tertarik dan menjadi pelanggan tetap pedagang tersebut.

Dalam hal memperluas jaringan beberapa pedagang kerajinan tenun ulos juga kerap kali datang ke rumah-rumah serta kantor-kantor untuk memamerkan ulos yang mereka jual. Biasanya rumah yang didatangi adalah rumah ibu-ibu yang ekonominya menengah ke atas. Para ibu ini biasanya akan memakai ulos ini disaat ada acara-acara pesta, dimana saat ini selain songket, ulos/songket Tarutung juga sudah mulai naik daun. Naik daunnya kerajinan tenun ulos/songket ini sejak dicanangkannya cinta akan produksi pakaian daerah oleh Presiden. Nantinya para ibu ini akan memanggil teman-temannya seperti keluarga, tetangga atau teman arisan untuk datang ke rumahnya bersama-sama melihat ulos yang dipamerkan. Ulos tersebut kemudian dibeli para ibu dan cara pembayarannya ada yang lunas ada pula dengan cicilan.

Jaringan sosial yang luas juga membantu proses pemasaran hingga ke luar kota. Jaringan sosial ini bermula dari kesan yang baik yang dirasakan pelanggan kemudian pelanggan saling bertukar nomor telepon dengan pedagang. Banyak pula pelanggan yang merujuk teman-temannya yang lain untuk membeli di salah satu kios langganannya di pasar. Kemudian para pelanggan akan memberikan kantongan pembungkus ulos kepada temannya. Kantongan pembungkus ulos menjadi media informasi tentang barang yang diperjualbelikan, alamat kios, nomor telepon dan nama media sosial pedagang. Kantongan pembungkus inilah yang membuat banyak pelanggan yang baru pertama kali datang dan membeli setelah dihunjuk temannya yang sudah berlangganan.

Pedagang Pasar sendiri mengakui kehadiran kantongan pembungkus ulos memberikan peran yang amat berarti bagi pemasaran ulos di luar kota. Pelanggan luar kota ada yang datang dari Pekanbaru, Jambi, Lampung, Jakarta, Bandung, Semarang, Surabaya, dan Papua. Menurut penenun dan pedagang kerajinan tenun ulos, daerah tujuan pendistribusian ulos yang paling banyak adalah Jakarta. Pelanggan luar kota yang membeli ulos di pasar Tarutung kebanyakan merupakan pedagang di luar kota. Di Jakarta para pedagang kerajinan tenun ulos berjulan di beberapa tempat seperti di ITC Mangga Dua, Pasar Senin, Tanah Abang, dan 
Cempaka Mas. Ada pula para pelanggan luar kota yang berjualan di kios atau ruko yang berada di luar kompleks pasar.

Pelanggan kerajinan tenun ulos yang ada di luar kota biasanya melakukan transaksi jual beli tiga kali dalam sebulan ke penenun dan pedagang ulos di Tapanuli Utara. Pelanggan ulos dari luar kota sering menelepon penenun dan pedagang agar ulos dikirim, karena keterbatasan waktu dan untuk meminimkan biaya pengiriman. Biaya pengiriman biasanya dilakukan melalui bank, dimana pelanggan luar kota langsung mentransfer uang ke nomor rekening penenun dan pedagang. Dalam hal pengiriman ulos ke luar kota para penenun dan pedagang biasanya memanfaatkan perusahaan jasa pengiriman atau ekspedisi.

Pelanggan yang berasal dari luar kota ada pula yang bukan berprofesi sebagai pedagang. Biasanya mereka datang langsung dari luar kota untuk membeli tenunan ulos. Tujuan mereka datang membeli ke pasar beragam, mulai dari ingin menambah koleksi, ingin memakainya pada saat ada acara adat hingga ingin menggunakan dalam pagelaran budaya.

Pedagang yang memiliki jaringan sosial yang luas hingga ke luar kota memiliki omset yang tinggi dibandingkan dengan pedagang yang memiliki sedikit jaringan ke luar kota. Adanya jaringan sosial yang luas akan semakin memperluas pemasaran sehingga frekuensi transaksi jual beli semakin tinggi dan mendapat keuntungan hingga puluhan juta setiap bulannya.

\section{Kesimpulan}

Perkembangan usaha pedagang merupakan hasil dari strategi adaptif yang dilakukan pedagang. Strategi lain yang dilakukan pedagang dalam pemeliharaan pola adalah membuat tampilan modern dengan cara tradisional tanpa meninggalkan nilai-nilai budaya (heritage) dalam proses produksi ulos. Adanya peningkatan mutu dan kualitas hasil-hasil kreasi kerajinan tenun ulos yang akan dijual, dimana melihat situasi dan kondisi masyarakat saat ini yang membutuhkan selera atau model baru maka pedagang kerajinanan tenun ulos mulai memodifikasi ulos-ulos yang diperjual belikan dengan tampilan yang baru. Jaringan sosial yang terbangun dalam cakupan internal pada sistem pemasaran yang terdapat di Pasar diawali dari adanya rasa percaya dan sifat kekeluargaan antara pedagang, pemasok / penenun, pegawai Pasar, satuan pengamanan dan organisasi kepemudaan. Rasa percaya telah menumbuhkan suatu relasi sosial yang 
kuat diantara pedagang dan pelanggan kerajinan ulos pada Pasar. Ada beberapa hal yang mempengaruhi terbangunnya jaringan antara pedagang dengan pelanggan yang bertujuan memperluas pemasaran, yaitu adanya interaksi sosial yang akrab diantara pedagang dan pelanggan, adanya pemanfaatan hubungan antara pelanggan dengan pedagang misalnya karena adanya ikatan kekeluargaan, teman lama, kenalan, tetangga dan teman seperkumpulan sosial dan arisan, yang nantinya mereka menjadi pelanggan tetap kios mereka.

Kedepan untuk memperluas pemasaran para pedagang pasar perlu semakin meningkatkan mengadakan kerja sama dengan pemerintah melalui Dinas Koperasi dan UKM melalui Program Nasional Pemberdayaan Masyarat (PNPM), Dewan Kerajinan Nasional Daerah (DEKRANASDA), sehingga mendapatkan berbagai bantuan seperti permodalan dan penyuluhan. Peran serta semua pihak (Stakeholder) yang terjalin antara penenun, pedagang, pemasok, pelanggan dan pemerintah yang didasari modal sosial di pasar perlu semakin ditingkatkan. Modal sosial yang terbagun perlu melibatkan peran serta pemerintah atau pembuat kebijakan agar kedepan setiap kebijakan yang ditetapkan pemerintah memberikan keuntungan kepada semua pihak.

\section{Endnote}

${ }^{1}$ George Rittzer, Douglas J. Goodman. Teori Sosiologi Modern. (Jakarta: Kencana, 2007), hlm. 121.

${ }^{2}$ Fukuyama, F. Trust: The Social Capital and the Creation of Prosperity. New York: Free Press, 1995), hlm. 27

3 Suyanto, Bagong, dan Sutinah. Metode Penelitian Sosial: Berbagai Alternatif Pendekatan. (Jakarta: Kencana, 2001), hlm. 166.

${ }^{4}$ Hadari Nawawi, Metode Penelitian Bidang Sosial. (Yogyakarta: Universitas Gadjah Mada Press, 1990), hlm. 203.

${ }^{5}$ Danandjaja. Metode Penelitian Sosial. (Medan: Universitas Sumatera Utara Press, 2005), hlm, 30 .

${ }^{6}$ George Rittzer, Douglas J. Goodman. Teori Sosiologi Modern. (Jakarta: Kencana, 2007), hlm. 121 .

${ }^{7}$ Damsar. Sosiologi Ekonomi. (Jakarta: PT Raja Grafindo Persada, 2002), hlm, 12.

${ }^{8}$ Badaruddin. "Modal Sosial dan Pemberdayaan Masyarakat Nelayan". Dalam Arif Nasution, Sublihar, Badaruddin (ed). Isu-isu kelautan: Dari Kemiskinan Hingga Bajak Laut. (Yogyakarta: Pustaka Pelajar, 2005), hlm. 32. 


\section{DAFTAR PUSTAKA}

Badaruddin. 2005. "Modal Sosial dan Pemberdayaan Masyarakat Nelayan". Dalam Arif Nasution, Sublihar, Badaruddin (ed). Isu-isu kelautan: Dari Kemiskinan Hingga Bajak Laut. Yogyakarta: Pustaka Pelajar.

Budiman, Arief. 2000. Teori Pembangunan Dunia Ketiga. Jakarta: PT Gramedia Pustaka Utama.

Bungin, Burhan. 2007. Penelitian Kualitatif. Surabaya: Kencana.

Damsar. 2002. Sosiologi Ekonomi. Jakarta: PT Raja Grafindo Persada.

Danandjaja. 2005. Metode Penelitian Sosial. Medan: Universitas Sumatera Utara Press.

Danim, Sudarwan. 2002. Menjadi Peneliti Kualitatif: Ancangan Metodologi, Presentasi, dan Publikasi Hasil Penelitian untuk Mahasiswa dan Peneliti Pemula Bidang Ilmu-ilmu Sosial, Pendidikan, dan Humaniora. Bandung: Penerbit Pustaka Setia.

Fukuyama, F. 1995. Trust: The Social Capital and the Creation of Prosperity. New York: Free Press.

Fukuyama, Fancis. 2002. Trust: Kebajikan Sosial dan Penciptaan Kemakmuran. Yogyakarta: Penerbit Qalam.

Hasbullah, Jousari. 2006. Social Capital (Menuju Keunggulan Budaya Manusia Indonesia). Jakarta: MR-United Press.

Lawang, Robert. 2004. Capital Sosial: Dalam Perspektif Sosiologis Suatu Pengantar. Jakarta: Fisip UI Press.

McClelland, David C. 1971. The Achievement Motive in Economic Growth dalam Finkle \& Gable (eds.), hal 83-100. Dikutip dari "Teori Pembangunan Dunia Ketiga" karya Arief Budiman. 
Harisan Boni: Strategi Adaptasi Pemasaran Kerajinan Tenun Ulos $\mid 47$

Nawawi, Hadari. 1990. Metode Penelitian Bidang Sosial. Yogyakarta: Universitas Gadjah Mada Press.

Rangkuti, Freddy. 2009. Strategi Promosi Yang Krearif. Jakarta: PT. Gramedia Pustaka Utama.

Ritzer, George, Douglas J. Goodman. 2007. Teori Sosiologi Modern. Jakarta: Kencana.

Ritzer,G. 2004. Teori Sosiologi Modern. Jakarta: PT. Rajawali Pers.

Sugiono.2005, Metodologi Penelitian Administrasi. Bandung: Alfabeta.

Suwarsono, Alvin Y. SO. 2006, Perubahan Sosial dan Pembangunan. Jakarta: LP3ES.

Suyanto, Bagong, dan Sutinah. 2008. Metode Penelitian Sosial: Berbagai Alternatif Pendekatan. Jakarta: Kencana.

Sztompka, Piotr. 2007. Sosiologi Perubahan Sosial. Jakarta: Prenada Media Group. 